\title{
Conceptual Unity and Associative Fields in Two of Quevedo's Sonnets
}

\author{
ROGER MOORE
}

Arthur Terry, following the lines of thought of James Smith 1 and A.A. Parker, ${ }^{2}$ has distinguished ornamental, or merely extravagant conceits, from organic ones. ${ }^{3}$ The former are defined as limited, selfcontained pieces of wit, whilst the latter are said to have an organic and continuing function within the poem. ${ }^{4}$ This often involves the elaboration or reinforcement of a central theme or idea. ${ }^{5}$ Although ornamental conceits are easily separable from organic ones in theory, it is not always simple to distinguish between them in practice, and the exact function of one of the conceits with which Terry chooses to illustrate his "ornamental" theory is open to debate.

The couplet which Terry quotes is the final conceit of Quevedo's madrigal entitled "Retrato de Lisi en mármol." This particular poem is not entirely original, Quevedo having translated it freely from a similar poem by L. Grotto, which begins "Un nobile scoltore ha di fatto...."6 The madrigal exists in two versions; the primitive text follows:
Un famoso pintor, Lisarda esquiva, te ha retratado en una peña viva, y ha puesto más cuidado en retratarte que la Naturaleza en engendrarte; pues si te dio blancura y pecho helado, él lo mismo te ha dado:
bellísima en el mundo te hizo ella, y él no te ha retratado menos bella. Mas ella, que te tuvo por piadosa, de hueso te compuso y carne hermosa, y él, que vuelta te mira en piedra ingrata, de lo que tú te has hecho te retrata. 7

The primitive version has obvious weaknesses, for example the repetition of retratar (lines 2, 3,8, and 12) and the conflict between escultor (later version and model) and pintor (primitive text only). The "texto de $A$ " is clearly later, as the reworking of lines $9-12$ shows: 8 


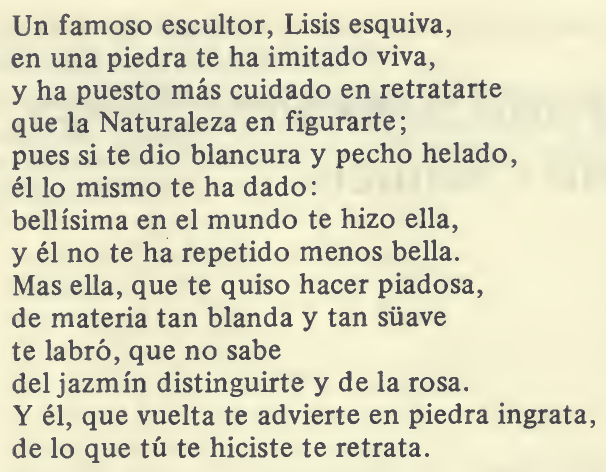

Quevedo eliminated the more obvious faults in his reworking of the poem. The pintor becomes an escultor, for this is, after all, a statue. Retratar is used only twice (lines 3 and 14), and is replaced by imitar and repetir in lines 2 and 8. Piedra replaces peña in line 2 as it is more in keeping with the final couplet's conceit. Similarly, whereas engendrar (primitive, line 4) describes a more or less biological function (Diccionario de autoridades: "Procrear el feto, mediante la unión del macho y de la hembra"), figurar (A, line 4) has artistic overtones (Diccionario de autoridades: "Disponer, delinear y formar la figúra de alguna cosa ... Formar el modelo, figurar la estatua, pulirla, reconocerla."). Quevedo's expansion of lines 9-12 is within the Petrarchan tradition, and the imagined softness of the roses and jasmines (A) contrasts more strongly with the statue's stone than do the harsher hueso and carne of the earlier version. Finally, it is to be noted that Quevedo keeps the epigrammatic last couplet. There are minor changes, but the basic conceit is in no way altered. It should be clear that in his reworking of the madrigal Quevedo eliminated superfluous material and accumulated imagery which would be in tune with the final conceit, for the last two lines are the climax of the poem. The hard-hearted lady has been imitated in a stone sculpture; conceit: she is now truly inard (stony) hearted.

It is difficult to agree with Terry when he writes that this couplet exemplifies "a self-contained piece of wit, indulged in for its own sake, which does not have any further purpose in its context." 9 Clearly this is an organic conceit, not an ornamental one, and its efficacy results from the accumulation, in the final version, of words and images which belong to what might be called the associative field of the central idea "hard-hearted lady - stone statue." "Escultor," "piedra," "imitar," "retratarte," "figurarte," "pecho helado," "repetido," "materia," 
"labró," "piedra," "retrata" - all these words belong to this associative field, and the conceit of the final couplet is central to it.

The concept of the associative field is usually regarded as linguistic in nature, but, with minor modifications, it is easily applicable to literary analysis. Ullman, following the line of thought of Saussure and Bally, has suggested that all words are surrounded by a network of associations which connect them with other words. These associations can be established by collecting "the most obvious synonyms, antonyms and homonyms of a word, as well as terms similar in sound or in sense, and those which enter into the same habitual combinations." 10

In this paper, I would like to propose that much seventeenth-century poetry can be analysed from the basis of the associative field; such an analysis will often lead the critic to a clearer grasp of the essential unity and meaning of the poem. I will illustrate this proposition with an analysis of two sonnets from the fourth muse of Francisco de Quevedo, "Al oro de tu frente unos claveles," and "Hermosísimo invierno de mi vida." 11 It will be seen from the analysis of the first sonnet that poetic unity can often be discovered within a given field.
$\mathrm{Al}$ oro de tu frente unos claveles
veo matizar, cruentos, con heridas;
ellos mueren de amor, y a nuestras vidas
sus amenazas les avisan fieles.
Rúbricas son piadosas y crueles, joyas facinorosas y advertidas, pues publicando muertes florecidas, ensangrientan al sol rizos doseles.
Mas con tus labios quedan vergonzosos
(que no compiten flores a rubíes)
y pálidos después, de temorosos.
Y cuando con relámpagos te ríes, de púrpura, cobardes, si ambiciosos, marchitan sus blasones carmesíes.

The associative fields in this poem are centred in lines 1 and 2 , with their hyperbolic extension to lines 3 and 4 , "like these flowers, so shall we die of the wounds of love." The associative fields are three in number:

(1) Colour (especially the colour red):

"oro," "claveles," "matizar," "cruentos," "heridos," "rúbricas," "crueles," "joyas," "florecidas," "ensangrientan," "sol," "labios," "vergonzosos," "flores," "rubíes," "pálidos," "relámpagos te ríes," "púrpura," "blasones carmesíes." 
(2) Flowers ("clavel" is the central image):

"clavel," "matizar," "muertes florecidas," "flores," "marchitar," "blasones carmesíes."

(3) Conflict (in association with the metaphors, "morir de amor" and "claveles crueles con heridas"):

"cruentos," "heridas," "mueren de amor," "nuestras vidas," “amenazas," “avisar," “fieles," “piadosas," “crueles,” “ensangrientan," "no compiten," "pálidos," "temorosos," "relámpagos," "cobardes."

The relationship between the associative field of colour and the words cruentos, rúbricas, and crueles is not immediately obvious. The Diccionario de autoridades defines them as follows: Rúbrica: (i) "la señal encarnada u rosa" (ii) "por alusión y semejanza se llama la sangre que se derrama para testificar alguna verdad." Cruel: "sangriento." Cruento: "sangriento y cruel." Their association with blood justifies their inclusion within this field. Our analysis of the poem will show that almost all of Quevedo's images are equally in keeping with one or another of the three associative fields which have already been isolated.

In lines 1 and 2, "Al oro de tu frente unos claveles,/veo matizar, cruentos, con heridas," the initial image is presented, along with the occasion (and remember that this is an occasional sonnet) on which it was written. Thus, the title of the poem, "A Flori que tenía unos claveles entre el cabello rubio," is expanded into the central image: the red carnations in Flori's hair are like open wounds.

Lines 3 and 4, "ellos mueren de amor, y a nuestras vidas/sus amenazas les avisan fieles," extend the image, and the flowers are now said to be dying of love. At the same time they warn us of our own fate at the hands of Flori.

Lines 5 and 6 continue the colour-images and empinasise the jewellery associations of "oro" in line 1, with the hyperbole of "joyas" in line 6 (and later "rubíes" in line 10). It must be noted, however, that whereas the flowers are generally termed "joyas," the beauties of Flori are likened more specifically to "oro" and "rubíes." A second point in these lines ("Rúbricas son piadosas y crueles,/joyas facinorosas y advertidas") is the association of "fieles" (4) with "piadosas," of "cruentos" (2) with "crueles," and of "avisan" (4) with "advertidas."12 The unusual colour associations of "rúbricas" and "crueles" should again be stressed.

Lines 7 and 8, "pues publicando muertes florecidas,/ensangrientan al sol rizos doseles," with their image of the carnations "publicando muertes florecidas," can now be appreciated in the light of what has gone before. The image is logical, as all good Baroque images should be, and the logic is that of the internal structure of the sonnet. In terms of 
association, "pu'licar" can be related to "avisar" (4) and "advertir" (6), whilst "muertes" returns us to "mueren de amor" (3), the extension of the original wounding-image. Similarly, "ensangrentar" is now a logical development of "Al oro de tu frente unos claveles/veo matizar," and the "sol" and "rizos doseles" refer back to "oro" and "claveles."

In lines $1-8$, the poet has expressed (1) the occasion, (2) the hyperbolic image drawn from it, and (3) the extension of that image to himself and to the reader. Now, in the first tercet, he develops the contrast between the flowers as decoration, and Flori as a real beauty:

Mas con tus labios quedan vergonzosos
(que no compiten flores a rubies)
y pálidos después, de temorosos.

This contrast, which was left implicit in the quatrains, now becomes explicit. Flowers, which were adornments, are seen in competition with (alas for the flowers) rubies. Through the outcome of this competition or conflict, a victory for Flori, colour is once more introduced into the imagery. The flowers are seen as "vergonzosos" (with its associated ideas of blushing and redness), and since they cannot compete their colour is seen to fade and they become "pálidos después, de temorosos."

At first glance, line 12 ("Y cuando con relámpagos te ríes") appears to be nothing more than an isolated ornamental conceit which is reminiscent of the "relámpagos de risa carmesíes" of the sonnet entitled "Retrato de Lisi que traía en una sortija."13 A closer analysis will show that the relámpagos supply the key to the final tercet, for not only do they have the double association of brightness and colourrevealing light, but they also cause the flowers to wither. Line 13 extends the "timorous" image of line 11: "de púrpura, cobardes, si ambiciosos," and the flowers are presented as both ambitious (anxious to compete) and cowardly (afraid of losing).

Line 14 brings the concluding image of the poem: "marchitan sus blasones carmesies"; such is the power of the lady's smile, that even the flowers wilt in comparison with it. The key-word is "marchitan," for the fate of the flowers is inextricably linked with their fate in line 3; the occasion has been rounded off with a poem of circular movement which returns to its origins: the comparison between the lady and the flowers. The poem is over, but the accumulation of colours remains illuminated by tinat final flash of the lady's laugh.

The lesser known, hence secondary, meanings of rúbrica, cruel, and cruento belong to the associative fields of these words, but although they add to the accumulative effect of conflict and colour, a knowledge 
of their significance betters our appreciation of the sonnet without greatly changing the poem's meaning. In the second sonnet, on the other hand, a comprehension of the full meaning will be impossible unless the correct secondary meaning of the adjective frágil is discovered. When this happens, our understanding of the poem is changed radically and the sonnet is wrenched out of the seemingly innocent Petrarchan tradition to which it had previously appeared to belong.

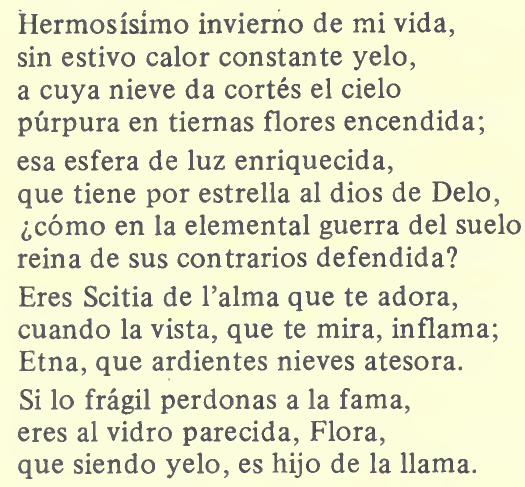

There are numerous contrasts within this poem, all of them based on the traditional Petrarchan opposition of fuego (fire of the lover) and yelo (ice of the beloved). If we take fuego and yelo to be the central points of two associative fields, the following patterns are perceived:

(1) Words associated with fuego and the "heat" of the lover: "estivo," "calor," "púrpura," "encendida," "flores," "esfera de luz," "dios de Delo," "adora," “inflama," "Etna," “ardiente," "llamas."

(2) Words associated with yelo and the "cold" of the beloved: "invierno," "sin estivo calor," "constante yelo," "nieve," "Scitia," "Etna,"14 "nieves," "vidro," "yelo."

This breakdown gives a clear picture of two separate states, heat and cold, which are in eternal strife. Both are intensified by an accumulation of words within their associative field. Thus, taking the poem line by line: "Hermosísimo invierno de mi vida" (with one of the rare superlatives to be encountered in the love poetry) sets the tone for the "cold" side of the poem. It is a hyperbole, and of course links the beloved with the seasons and more particularly with winter's cold.

"Sin estivo calor constante yelo" doubles the effect with a series of contrasts within the line. "Calor" is contrasted with "yelo," "estivo calor" (the heat of mid-summer) with "constante yelo" (the cold of mid-winter). Preceded by "sin," however, "estivo calor" is suggestive 
of the "constante yelo" which follows it. "Invierno" in line 1 is emphasised by "constante yelo," and contrasted with "estivo calor."

Line 3 continues the winter images: "a cuya nieve da cortés el cielo"; whilst line 4, "púrpura en tiernas flores encendida," with its images of colour and flowers, contrasts the winter with the spring. The word "púrpura," as well as intimating a touch of colour to compare with winter's whiteness, also provides the contrast of hot and cold, for the "púrpura" is "encendida." Finally, "púrpura," the imperial colour, is in tone with the regal word "reina," in line 8.

"Cielo," in line 3, leads to the facial images of the next two lines: "esa esfera de luz enriquecida;/que tiene por estrella al dios de Delo." Here, the images "esfera de luz enriquecida," "estrella," and "dios de Delo," have as the centre of their associative field (1) "cielo," and (2) the metaphor, face as the sky or sun. The two lines give a hyperbolic image of the beauty of the beloved. This beauty is that of the sun, and once again the contrast with the early "yelo" elements is established.

"Cielo" extends its influence to line 7, where it is contrasted with "suelo" (this contrast is accentuated by the rhyme): "icómo en la elemental guerra del suelo/reina de sus contrarios defendida?" In these two lines the poet emphasises the idea of contrast: "guerra," and "contrarios." It is intensified by the image of line 8, that "esa esfera de luz" - "reina de sus contrarios defendida." That is to say, it is defended from its opponents.

The first tercet extends the contrasts, further defining the beloved's relationship to the lover:

Eres Scitia de l'alma que te adora, cuando la vista, que te mira, inflama;

Etna, que ardientes nieves atesora.

Thus, "Scitia de l'alma" contrasts with "adora" and "inflama," and is intensified by the image of "Etna" and its "ardientes nieves," where noun and adjective would clash violently if the paradox were not acceptable within the context of the poem.

The conceit found in the second tercet is best introduced by quoting the note which González de Salas appended to Quevedo's sonnet "En breve cárcel traigo aprisionado ...." Commenting on the first tercet,

Traigo todas las Indias en mi mano, perlas que, en un diamante, por rubíes, pronuncian con desdén sonoro yelo,

González de Salas wrote, "Era pues diamante la boca, porque lo que 
hablaba eran desdenes y signifícalo diciendo que pronunciaba sonoro yelo, y alude a la opinión de los que quieren que el cristal sea yelo intensamente congelado, y el diamante más intensamente."15 In this way, the final image is presented as another step in the fuego-yelo series. The conceit is an important one, however, for, in the same way that cold formed from heat is the making of glass (vidro-yelo), so cold is formed from Flora when she is exposed to the heat of the lover's emotion:

Si lo frágil perdonas a la fama, eres al vidro parecida, Flora, que siendo yelo es hijo de la llama.

The importance of secondary meanings in the poety of Quevedo has been established by Lapesa. ${ }^{16}$ This point has also been stressed by García de Diego, who shows that although one can study Quevedo's vocabulary with the aid of an ordinary dictionary, the task is futile because "todo allí está dislocado y las palabras no son lo que el léxico indica." 17

In this instance, the dislocation stems from the double value assigned to a single word in the final tercet. Thus Flora is compared to glass for the perfectly normal reason that glass, which is cold, is manufactured in a scientific process involving heat. Flora, too, is cold, even though she is exposed to the heat of the poet's love. Glass has a second quality, it is fragile. Flora is also a fragile, delicate person; this is the ordinary rendering which could be expected from an understanding of Petrarchan tradition.

This straightforward interpretation should fail to satisfy, and line 12 , "si lo frágil perdonas a la fama," should be enigmatic. Why should one perdonar lo frágil? Is Flora ill (fragile, delicate)? Or does frágil have a secondary meaning which is not immediately obvious? Clearly the latter supposition is correct, and the Diccionario de autoridades helps solve the riddle. Frágil means (i) "quebradizo y que con gran facilidad se hace pedazos... como el vidro, barro etc." This gives the Petrarchan interpretation. (ii) "Se llama también la persona que cae en un pecado, especialmente contra la castidad." Frágil, then, has the meaning of "breakable" when applied to glass, but of "sinning against chastity" when applied to a woman. Now the enigma of the twelfth line is clarified and it is no wonder that Quevedo wrote "si lo frágil perdonas a la fama."

The new meaning which can now be assigned to frágil wrenches this beautiful sonnet away from the polite Petrarchan tradition, for Quevedo, in a subtle and underhand fashion, has used a cleverly concealed conceit to suggest that Flora, although corresponding to some of 
the traditional elements of Petrarchism, is not chaste. The "hot" elements of the poem now take on added meaning and one reflects anew on the virtues concealed within such lines as "Etna, que ardientes nieves atesora." Quevedo shows in a poem based on antitheses that Flora herself is an antithesis: she is not what she appears to be.

Although at the Petrarchan level much of the vocabulary may be classified as trite, well-worn, or clichéd, the sonnets (and the second one in particular) present themselves with a freshness that is startling. This springs from a unity of imagery. There is nothing wasted, nothing superfluous, and, within the associative fields meaning and secondary meaning interact to give various levels of significance. Each conceit has its place within the field and each word elaborates and reinforces the central theme thus contributing to the essential unity of the whole.

It should now be clear that an understanding of the concept of the associative field will often aid the critic in grasping more clearly the conceptual unity of seventeenth-century poetry. In particular, it will facilitate the distinction between ornamental and organic conceits, for the former are usually isolated whilst the latter often belong to an associative field.

\section{St. Thomas University}

\section{Notes}

1 James Smith, “On Metaphysical Poetry," Scrutiny, 2 (1933), 222-39, especially pp. 231-32.

2 A.A. Parker, "La agudeza en algunos sonetos de Quevedo," Estudios dedicados a Menéndez Pidal, 3 (1952), 345-60.

3 Arthur Terry, "Quevedo and the Metaphysical Conceit," Bulletin of Hispanic Studies, 35 (1958), 211-22.

4 Arthur Terry, "Quevedo," p. 213.

5 F. Lázaro Carreter, "Sobre la dificultad conceptista," Estudios dedicados a Menéndez Pidal, 6 (1956), 355-86.

6 See Francisco de Quevedo, Obra poética, ed. J.M. Blecua, I (Madrid, 1969), p. 678.

7 Francisco de Quevedo, Obra poética, ed. J.M. Blecua, I (Madrid, 1969), pp. 678-79. All references to Quevedo's poetry are from this edition, which will henceforth be referred to as JMB, 1969.

8 See JMB, 1969 , p. 678.

9 Arthur Terry, "Quevedo," p. 213.

10 Stephen Ullman, Semantics (1962: rpt. Oxford, 1967), pp. 238-43.

$11 \mathrm{JMB}, 1969$, pp. 514 and 507-08.

12 Footnote of G. de Salas: "Que advierten, son participios nuestros que significan acción y pasión, como los de los latinos entendido, el que entiende y lo que es entendido."

13 JMB, 1969, p. 653.

14 The image of Etna in Quevedo's verse contrasts the volcano (fire of love) with the snowy peak (cold of the beloved).

15 JMB, 1969, p. 653.

16 Rafael Lapesa, Historia de la lengua española, 7th ed. (Madrid, 1968), p. 232.

17 Vicente García de Diego, Lecciones de lingüistica española (Madrid, 1960), p. 55. 